\title{
IfIISGUC.ORG
}

"iș, GÜC̣" ENDÜSTRi iLișKiLERi VE inSAN KAYNAKLARI DERGiSi

"IS, GUC" INDUSTRIAL RELATIONS AND HUMAN RESOURCES JOURNAL

\section{Adalet Algısı ve Tükenmişliğin Örgütsel Vatandaş- lık Davranışları Üzerindeki Öncüllük Rolü}

The Antecedent Role Of Justice Perception and Burnout
On Organizational Citizenship Behaviors

\section{Cem Harun MEYDAN}

Dr., Kara Harp Okulu

Harun ŞEŞEN

Dr., Kara Harp Okulu

H. Nejat BASIM

Doç Dr., Başkent Üniversitesi

Nisan/April 2011, Cilt/Vol: 13, Say1/Num: 2, Page: 41-62

ISSN: 1303-2860, DOI: 10.4026/1303-2860.2010.0172.x

Makalenin on-line kopyasına erişmek için:

http://www.isguc.org/?p=article\&id=455\&vol=13\&num=2\&year=2011

To reach the on-line copy of article:

http://www.isguc.org/?p=article\&id $=455 \& v o l=13 \&$ num $=2 \& y e a r=2011$

Makale İçin İletişim/Correspondence to: 
(C) 2000- 2011

"İşGüç" Endüstri İlişkileri ve İnsan Kaynakları Dergisi

"İşGüç" Industrial Relations and Human Resources Journal

Nisan/April 2011, Cilt/Vol: 13, Say1/Num: 2

ISSN: 1303-2860, DOI: 10.4026/1303-2860.2010.172.x

Editör/Editor-in-Chief

Aşkın Keser (Kocaeli University)

Editör Yardımcıları/Co-Editors

K.Ahmet Sevimli (Uludağ University)

Gözde Yılmaz (Kocaeli University)

Uygulama/Design

Yusuf Budak (Kocaeli Universtiy)

\author{
Yayin Kurulu / Publishing Committee \\ Dr.Zerrin Firat (Uludă̆ University) \\ Doç.Dr.Așkm Keser (Kocaeli University) \\ Prof.Dr.Ahmet Selamoğlu (Kocaeli University) \\ Yrd.Doç.Dr.Ahmet Sevimli (Uludağ University) \\ Yrd.Doç.Dr.Abdulkadir Şenkal (Kocaeli University) \\ Yrd.Doç.Dr.Gözde Yilmaz (Kocaeli University) \\ Dr.Memet Zencirkıran (Uludă̆ University)
}

Uluslararası Danışma Kurulu / International Advisory Board

Prof.Dr.Ronald Burke (York University-Kanada)

Assoc.Prof.Dr.Glenn Dawes (James Cook University-Avustralya)

Prof.Dr.Jan Dul (Erasmus University-Hollanda)

Prof.Dr.Alev Efendioğlu (University of San Francisco-ABD)

Prof.Dr.Adrian Furnham (University College London-İngiltere)

Prof.Dr.Alan Geare (University of Otago- Yeni Zellanda)

Prof.Dr. Ricky Griffin (TAMU-Texas AEM University-ABD)

Assoc. Prof. Dr. Diana Lipinskiene (Kaunos University-Litvanya)

Prof.Dr.George Manning (Northern Kentucky University-ABD)

Prof. Dr. William (L.) Murray (University of San Francisco-ABD)

Prof.Dr.Mustafa Özbilgin (University of East Anglia-UK)

Assoc. Prof. Owen Stanley (James Cook University-Avustralya)

Prof.Dr.Işık Urla Zeytinoğlu (McMaster University-Kanada)

Danışma Kurulu / National Advisory Board

Prof.Dr.Yusuf Alper (Uludağ University)

Prof.Dr.Veysel Bozkurt (Uludağ University)

Prof.Dr.Toker Dereli (Işık University)

Prof.Dr.Nihat Erdoğmuş (Kocaeli University)

Prof.Dr.Ahmet Makal (Ankara University)

Prof.Dr.Ahmet Selamoğlu (Kocaeli University)

Prof.Dr.Nadir Suğur (Anadolu University)

Prof.Dr.Nursel Telman (Maltepe University)

Prof.Dr.Cavide Uyargil (İstanbul University)

Prof.Dr.Engin Yildirum (Sakarya University)

Doç.Dr.Arzu Wasti (Sabancı University)

Dergide yayınlanan yazılardaki görüşler ve bu konudaki sorumluluk yazarlarına aittir.

Yayınlanan eserlerde yer alan tüm içerik kaynak gösterilmeden kullanılamaz.

All the opinions written in articles are under responsibilities of the outhors.

None of the contents published can't be used without being cited. 


\title{
Adalet Algısı ve Tükenmişliğin Örgütsel Vatandaşlık Davranışları Üzerindeki Öncüllük Rolü
}

\author{
The Antecedent Role Of Justice Perception and Burnout On \\ Organizational Citizenship Behaviors
}

\author{
Cem Harun MEYDAN \\ Dr., Kara Harp Okulu
}

\author{
Harun ŞEŞEN \\ Dr., Kara Harp Okulu
}

\author{
H. Nejat BASIM \\ Doç Dr., Başkent Üniversitesi
}

\begin{abstract}
Özet:
Örgütsel vatandaşlık davranışları (ÖVD), örgütü yıkıcı ve istenmeyen davranışlardan koruyarak, örgütün performansını ve verimliliğini artırıcı etkiler yaratabilmektedir. Örgüt içinde birey davranışları üzerinde etkili olan farklı örgütsel faktörler bulunmakta, bu faktörler bireylerin ÖVD'lerinin de üzerinde etkili olabilmektedir. Bu çalışma, bu faktörlerden, adalet algısı ve tükenmişliğin ÖVD üzerindeki öncüllü̈k rolünü bütüncül bir bakış açısı ile ele almayı hedeflemektedir. Bu maksatla 116 alt ve orta kademe kamu yöneticisinden veri toplanmış ve yapısal eşitlik modeli çerçevesinde analiz yapılmıştır. Elde edilen bulgular, çalışmada ele alınan değişkenler arasındaki ikili ilişkileri inceleyen önceki çalışmaların bulguların desteklemekte; hem de bir bütün olarak ele alındığında, adalet algisının bireylerin tükenme duyguları üzerinde azaltıcı yönde bir etkiye sahip olduğu ve bireylerin tükenmişlik duygularmın ÖVD'nin önemli bir yordayıcısı olduğunu göstermektedir.
\end{abstract}

Anahtar Kelimeler: Örgütsel davranış, adalet algısı, tükenmişlik, örgütsel vatandaşlı davranışları, aracılık etkisi

\begin{abstract}
:
Organizational citizenship behaviors (OCB) can be effective on the organization's performance and may have an impact on the productivity increase by protecting organizations from destructive and unwanted behaviors. Different organizational factors may influence individual behavior within the organization. These factors may also have an effect on the OCB of individuals. This study aims to address the antecedent role of organizational justice perception and burnout on OCB with a holistic perspective. For this purpose the data were collected from 116 lower and middle-level public managers and analyzed in the structural equation model framework. The results support the findings of the previous studies which examined bilateral relations of the variables, as well as, taken the relationships as a whole; justice perception has both a decreasing effect on burnout feelings of the individuals and individuals' burnout feelings are important predictors of OCB.
\end{abstract}

Keywords: Organizational behavior, justice perception, burnout, organizational citizenship behavior, mediation 


\section{GíRiş}

Günümüzde, örgütlerin yönetsel etkililiğini ve verimliliğini artırmaya yönelik birçok araştırma yapılmaktadır. $\mathrm{Bu}$ araştırmaların büyük kısmı, örgütsel yapının yanı sıra örgütlerde çalışanların davranışlarının anlaşılması, temellendirilmesi ve yönlendirilmesine yönelik olmaktadır. Anılan çalışmalarda odaklanılan konulardan birisi de Örgütsel Vatandaşlık Davranışları (ÖVD)dır. Çalışanların biçimsel rollerinin ötesinde, herhangi bir emir ya da talimata dayalı olmadan sergilenen ve örgüte katkı sağlayan davranışlar olarak tanımlanan (Organ, 1988:4) örgütsel vatandaşlık davranışları, örgütü yıkıcı ve istenmeyen davranışlardan koruyarak, örgütün performansını ve verimliliğini artırıcı etkiler yaratabilmektedir (Lapierre ve Hackett, 2007). Bununla birlikte, örgüt içinde birey davranışları üzerinde etkili olan farklı örgütsel faktörler bulunduğundan, ÖVD'nin de bu faktörlerden etkilenmesi söz konusu olmakta; buradan hareketle, hem konuya yönelik kurama katkı hem de etkili uygulamalar açısından, çalışan bireylerin örgütsel vatandaşlık davranışları göstermelerini etkileyebilecek faktörlerin ortaya konması büyük önem arz etmektedir. Bireylerin örgüt içinde algıladıkları adalet ve hissettikleri tükenmişlik, ÖVD üzerinde etkili olabilecek faktörler olarak görülmektedir. Zira anılan iki faktör de bireylerin örgüt içinde davranışları üzerinde oldukça etkili olmaktadır.

Bu çalışmanın amacı söz konusu faktörlerden örgütsel adalet algısı ve tükenmişlik ile ÖVD arasındaki ilişkiyi inceleyerek, örgütsel adalet algısı ve tükenmişliğin ÖVD üzerindeki öncüllük rolünü ortaya koymaktır. Zira hem adalet algısı ve tükenmişlik örgüt içinde birey davranışı üzerinde etkili olan faktörlerdir; hem de bu üç değişkeni bütüncül olarak bir arada ele alan bir çalışmaya rastlanmamıştır. Bu amaçla, çalışmada öncelikle konunun kuramsal çerçevesine yer verilmekte, kuramsal gerekçeler 1 şı̆̆ında oluşturulan bir model ile muhtemel ilişkiler incelenmektedir.

\section{KURAMSAL ÇERÇEVE}

\section{1. Örgütsel Vatandaşlık Davranışları}

Örgüt için fayda sağlayan fakat herhangi bir emre dayalı olmayan davranış ve hareketler, çalışanların görevlerinin gerektirdiği biçimsel rol davranışlarından farklılık gösterir. Bu biçimsel olmayan davranışlar, yönetim yazıninda prososyal (olumlu sosyal) örgütsel davranış (Brief ve Motowidlo, 1986; McNeely ve Meglino, 1994), ekstra rol davranışı (Van Dyne ve diğ., 1994), iyi asker sendromu (Turnipseed ve Murkison, 1996, 2000; Organ, 1988), bağlamsal performans (Van Scotter ve Motowidlo, 1996) ve örgütsel vatandaşlık davranışları (Bateman ve Organ, 1983; Organ, 1988; Smith ve diğ., 1983) olarak adlandırılmaktadır. Söz konusu davranışlar, diğer çalışanların hatalı davranışlarına duyarsız kalmama, onlarla konuları tartışma, gerektiğinde onları yönetime şikâyet etme gibi çeşitli eylemlerin yanı sıra; işi zamanından önce bitirme, yenilikçi olma, diğerlerine yardım etme ve gönüllü olma gibi sosyal davranışları da içerir (Özdevecioğlu, 2003).

ÖVD, "işbirliği yapma arzusu" ve "bağımlı rol performansı ile yaratıcı ve spontan davranışlar arasındaki ayrım" şeklinde tanımlanan düşünceleri temel alan davranışlardır (Podsakoff ve diğ., 2000). İlk kez 1983 yılında kullanılmış olan ÖVD kavramı, "biçimsel ödül sistemini dikkate almaksızın, bir bütün olarak örgütün fonksiyonlarını verimli ve etkili biçimde yerine getirmesine yardımcı olan, gönüllülük esasına dayalı birey davranışları" olarak tanımlanmaktadır (Organ, 1988:4). Bu tür davranışlar görev ve iş tanımlarında zorunlu tutulmayan, ihmali halinde ceza gerektirmeyen ve daha çok kişisel tercih sonucu sergilenen davranışlardır (Podsakoff ve diğ., 2000: 513).

Konuyla ilgili yazın incelendiğinde örgütsel vatandaşlık davranışlarına yönelik farklı boyutlandırmalar olduğu görülmektedir. Bir çalışmada 30 farklı vatandaşlık davranışı ortaya konurken (Podsakoff ve diğ., 2000), farklı bir çalışmada iki vatandaşlık davranışından bahsedilmektedir (Smith ve 
diğ., 1983). Yazında genel kabul görmüş olan boyutlandırmanin ise ekstra rol davranışı tanımını geliştirerek "örgütsel vatandaşlık davranışları" kavramını ortaya koymuş olan Organ (1988)'ın önerdiği beş boyutlu bir yapı olduğu görülmektedir (Hannam ve Jimmieson, 1999; Hardeep, 2010; Hoffman ve diğ., 2007; LePine ve diğ., 2002; Podsakoff ve Mackenzie, 1997). Bu boyutlar diğergamlik (diğerlerini düşünme), nezaket, vicdanl1lık (ileri görev bilinci), sivil erdem (örgüt gelişimine destek verme) ve centilmenlik olarak isimlendirilmektedir. Bu boyutlar aşağıda kısaca açıklanmıştır.

Diğergamlık: $\mathrm{Bu}$ boyut, diğer kişilere yardım etmeye veya işle ilişkili sorunların ortaya çıkmasını önlemeye yönelik gönüllü davranışları içermektedir (Graham, 1989; Organ ve Konovsky, 1989; George ve Jones, 1997; Podsakoff ve diğ., 2000). Podsakoff ve arkadaşları (1990) diğergamlığı, bir sorun oluştuğunda çalışanların; uzman kişilere yardımcı olmayı amaçlayan ve bu durumda çalışanların daha verimli çalışmasını sağlayan davranışlar olarak belirtmişlerdir. Uzman kişilerin (ör: ustabaşılar) ya da k1demli çalışanların hiç bir ücret almaksızın, yeni meslektaşlarına yardım etmesi de bu kapsamda sayılabilir. Benzer şekilde bir çalışanın diğer bir çalışanın rahatsızlığı nedeniyle onun işini üstlenmesi davranışı bu boyuta örnek olarak verilebilir (Kidwell ve diğ., 1997). Bu tür davranışlar, bireylerin performanslarını geliştirerek grup verimliliğine katkıda bulunurlar.

Vicdanlılık: İkinci boyut, çalışanların kendilerinden beklenen asgari rol davranış1nın ötesinde bir rol davranışını gönüllü olarak sergilemelerini ifade etmektedir (Organ, 1988). Bu, bir anlamda çalışanın, örgütün kural, düzenleme ve süreçlerini içselleştirmesi ve kabul etmesinin göstergesidir. Bu davranışın örgütsel vatandaşlık davranışının bir biçimi olarak kabul edilmesinin sebebi, her çalışandan, örgütün kural, düzenleme ve süreçlerine her zaman uygun hareket etmesi beklenmesine rağmen, aslında pek çoğunun buna uygun davranmamasıdır (Podsakoff ve diğ., 2000: 528).
Kişiliğin temel kategorilerini tanımlamak amacıyla kullanılan ve organize olma, güvenilir olma ve başarmaya isteklilik gibi bir takım özellikleri içeren vicdanlılık, temelde çalışanın genel itaatini yansıtsa da, aslında önemli olan çalışanın kimsenin kendisini izlemediği durumda da örgütün kurallarına uygun hareket etmesini içermektedir (Barksdale ve Werner, 2001: 148).

Nezaket: Bu boyut başkalarının işlerini etkileyecek hareketler yapmadan veya kararlar almadan önce onları bilgilendirmeye dayanan davranışları ifade etmektedir (Deluga, 1995: 2). Bu nedenle nezaket, problemleri önlemede önemli rol oynar ve zamanın yapıcı bir biçimde kullanılmasını kolaylaştırır. Bir örgütte olumlu iklimin yakalanıp performansın artırılabilmesi için, birbirleriyle iletişimde bulunan bireylerin karşılıklı olarak olumlu davranışlar sergilemeleri gerekir. Nezakete dayalı davranışlar, daha çok gelecek odaklı davranışlar olarak ifade edilmektedir. Örneğin, diğergamlık davranışı, biçimsel görevlerin ötesinde performans faaliyetleri ile ilişkiliyken; nezaket, doğru ve uygun gelecekte olası problemlerin oluşmasını engelleyen davranışları kapsamaktadır (Burns ve Collins, 2000).

Sivil Erdem: Bu davranışlar çalışanların örgütün politik yaşamına katılımını gösteren yardımcı faaliyetleri içermektedir. Sivil erdem davranışı örgütü etkileyen olaylara karşı çalışanların kendilerini sorumlu kılmaları ve kararlara sorumlu ve gönüllü bir şekilde katılmalarıdır (Schnake ve Dumler, 1993: 352). Burada bireysel inisiyatif söz konusudur ve bireylerin örgütle ilgili konularda tartışması, sorunlara yönelik çözüm önerileri geliştirmesi ve alınan kararlara katılımı içerir (Thompson ve Werner, 1997: 590; Kidder, 2002: 637). Çalışanların örgüt imajına katkıda bulunan faaliyetlere katılması sivil erdem davranışına verilebilecek iyi bir örnektir (Bolino, 1999).

Gönüllülük ve Centilmenlik: İşe ilişkin kaçınılmaz sorunları veya zorlukları şikayet etmeden kabul etme istekliliği olarak tanımlanabilir (Podsakoff ve diğ., 2000: 639). Ĕger 
çalışanlar sürekli şikâyet eder, işin olumlu yönlerinden çok olumsuz yönlerine odaklanır, en küçük sorunları bile aşırı büyütürlerse, örgütsel iyilik halinin ve olumlu bir örgüt ikliminin yakalanması mümkün olamaz. Gönüllülük ve centilmenlik, örgütün liderine ve örgüte bir bütün olarak bağlılı̆̆1 gerektirir (Netemeyer ve diğ., 1997: 86). Diğer bir açıdan bakıldığında, bu tür davranışların olmaması çalışanların örgüte karșı sadakat duygusunun azalmasina sebep olabilmektedir (Bommer ve Lilly, 1994).

ÖVD'nin yukarıda ifade edilen boyutları iki ayrı grupta toplanarak "kişiye yönelik ÖVD" ve "örgüte yönelik ÖVD" olarak da belirtilmektedir (Williams ve Anderson, 1991). Diğergamlık ve nezaketin örgüt içi çalışan bireylere yönelik; vicdanlılık, sivil erdem ve centilmenliğin ise örgüte yönelik ÖVD’leri kapsadığı ifade edilmektedir.

ÖVD ile ilgili yapılmış olan çalışmalar, ÖVD'nin öncüllerinin bireysel özellikler, görev özellikleri, örgütsel özellikler ve liderlik davranışları şeklinde dört temel kategoride toplandığını göstermektedir (Podsakoff ve di.̆., 2000). ÖVD konusundaki öncül çalışmalarda, bireylerin özelliklerinin ÖVD üzerinde etkili olacağı düşünülerek (Bateman ve Organ, 1983; O'Reilly ve Chatman, 1986; Smith ve di ğ., 1983) eğilimsel ve ahlâki değişkenler olmak üzere iki temel alana odaklanılmıştır. Birinci alan olan eğilimsel değişkenlerin ÖVD ile ilişkisi araştırılmış ve ÖVD'yi etkilediği ortaya konmuştur (Podsakoff ve diğ., 2000). Diğer alan olan ahlâki değerler (Organ ve Ryan, 1995) kapsamında ise iş tatmini, dürüstlük alg1s1, örgütsel bağlılık ve algılanan lider desteği, ÖVD ile ilişkisi en çok araştırılan öncüller olarak göze çarpmaktadır. Ahlâki değerler konusundaki araștırmalar (Bateman ve Organ, 1983; O’Reilly ve Chatman, 1986; Organ ve Ryan, 1995; Smith ve diğ., 1983), ÖVD'nin tüm bu özelliklerle az ya da çok ilişkili olduğunu ortaya koymuştur. Bu bağlamda değerlendirildiğinde çalışanların adalet algıları, ahlâki değerler kapsamında ÖVD'nin öncülü olarak üzerinde çalışılmış (Ryan, 2002) önemli bir faktördür.

\section{2. Örgütsel Adalet Algisı}

Örgüt içinde algılanan adalet, bireylerin örgüt dâhilinde kendilerine karşı adil olunup olunmadığ 1 konusunda yargiya varmalarını sağlamaktadır. Bireyler örgütteki süreç ve mekanizmaların, görev ve ödüllerin, kendilerine gösterilen davranışın adaletli olup olmadığı konusunda yargıya varmakta ve bu yargı sonucunda örgüte ve dolayısıyla işlerine karşı tutum geliștirmektedirler (Greenberg, 1990: 399). Bireyler örgüt içinde adalete fazlasiyla önem vermekte (Folger, 1998) ve bunun sonucu olarak, örgütsel adalet alg1S1, bireylerin örgüte bağl1lığını, tatminini, örgütten geri çekilme davranışını, örgütle özdeşleşmesini, örgütsel vatandaşlık davranışı göstermesini ve örgüte duyulan güveni etkileyebilmektedir (Ambrose, 2002; Cohen-Charash ve Spector, 2001; Lee, 2001; Viswesvaran ve Ones, 2002; Zhang, 2006).

Örgüt içinde adalet araştırmaları son otuz beş yıldır araştırmacıların ilgisini çekmekte (Ambrose, 2002: 803) ve örgütsel adalet çalışmaları Adams (1965)'ın “Eşitlik Kuramı"na kadar dayandirılmaktadır. Konuya ilişkin araştırmaya dayalı bilginin, zaman içinde yapılan birçok çalışma ile geliştirildiği görülmektedir (Ambrose, 2002; Bies ve Moag, 1986; Cohen-Charash ve Spector, 2001; Colquitt, 2001; Greenberg, 1990; 1993; Nowakovski ve Conlon, 2005; Thibaut ve Walker, 1975). Anılan çalışmalar değişik bakış açılarıyla yapılmış ve bu çalışmalar örgütsel adaletin alt boyutlarını ortaya koymuştur. Adalet algısı boyutları dağıtım adaleti, süreç adaleti ve etkileşim adaleti olarak üç boyut halinde belirtilmekle birlikte, bazı araştırmacıların (Colquitt ve diğ., 2001), adalet algısını dağıtım adaleti, süreç adaleti, bireylerarası adalet ve bilgisel adalet olarak dört boyutlu yapıda ele aldığ 1 da görülmektedir. Bu çalışmada üç boyutlu yapı ele alınmış ve bu boyutlar aşağıda kısaca açılanmıştır.

Dağıtım Adaleti: Dağıtım adaleti, bir çalışanın, işe yaptığ 1 katkılar ve bu katkılar sonucunda karşılaştığ1 ödül, görev, sorumluluklar gibi iş ile ilgili sonuçları, 
diğer çalışanların katkı dereceleri ve karş1laştıkları sonuçlar ile kıyaslaması sonucunda algıladığ 1 adalettir (Greenberg, 1990: 400). Çalışanlar tarafından karşılaşılan sonuçların adil dağılmış olması bu algıyı oluşturmaktadir (Andersson-Stråberg ve diğ., 2007). Dağitım adaleti, örgütte otoritenin değerlendirilmesi, iş tatmini, örgütsel bağl1lık ve güven gibi çalışanların örgüt içi tutum ve davranışlarıyla doğrudan ilişkilidir (Colquitt ve diğg., 2001).

Süreç Adaleti: Çalışanların algılamalarının sadece sonuçlarla değil; bu sonuçlara ulaşmada kullanılan süreçlerle de ilgili olduğunun fark edilmesi sonucunda, dağıtım adaletinin, örgüt içindeki adalet algısının açıklanmasında yetersiz olduğunu görülmüș ve kararlara ulaşmada kullanılan süreçlerin de adilliğini tanımlayan süreç adaleti kavramı geliştirilmiştir (Nowakovski ve Conlon, 2005). Süreç adaleti, yönetici tarafindan verilen bir kararın sonucu ne olursa olsun, kontrollü bir süreç sonunda alındığ takdirde, adil olarak algılandığını ifade etmektedir (Thibaut ve Walker, 1975). Başka bir deyişle süreç adaleti, sonuçların dağıtılmasında kullanılan yöntemlerin adil olarak algılanmasıyla ilgili olup (Irak, 2004); dağ1tım adaleti gibi, çalışanların örgüt içindeki tutum ve davranışlarını etkilemektedir (Ambrose, 2002).

Etkileşim Adaleti: Bireylerin süreçleri uygulayış şekillerinin farklı olmasının, örneğin, bir örgütte performans değerlendirme işleminin farklı yöneticiler tarafından farklı uygulanmasının, çalışanların birbirinden değişik tepkiler vermesine neden olduğu tespit edilmiş ve bu da etkileşim adaleti ile ilgili çalışmaların yapılmasında çıkış noktası olmuştur (Bies ve Moag, 1986). Etkileşim adaleti, adalet çalışmalarının sosyal yönünü oluşturmakta ve bireyler arasındaki ilişkinin kalitesine işaret etmektedir (Ambrose, 2002: 804). Etkileşim adaleti, çalışanların örgüt içinde karar vericilerin kendilerine karşı tavırlarının ve örgüt içinde alınan kararlar ile ilgili yapılan açıklamaların bireylerin adalet algılamalarını etkilediğini ifade etmektedir (İşbaşı, 2001: 60).

\subsection{Tükenmişlik}

Tükenmişlik, salt yorgunluk, yıpranma ve iş doyumsuzluğundan farklı olarak; fiziksel bitkinlik, çaresizlik ve ümitsizlik duygularını, olumsuz benlik gelişimiyle işe yaramama hissini ve diğer insanlara yönelik olumsuz tutumları içeren fiziksel, duygusal ve zihinsel bir durumdur (Maslach ve diğ., 1981).

Tükenmişlik, "enerji, güç veya kaynaklar üzerindeki aşırı istekler, taleplerden dolayı tükenmeye başlamak" ve "başarısızlık, yıpranma veya enerji, güç ve potansiyel üzerindeki aşırı zorlanma sonucunda ortaya çıkan bir tükenme durumu" olarak tanimlanmakta (Freudenberger, 1974); sebebi ne olursa olsun, anılan özellikleriyle bu süreç, kişiyi hem özel yaşantısında hem de iş yaşant1sinda etkisiz hale getirebilmektedir. Tükenmişliğin, genelde insanlara yardım hizmeti sunan mesleklerde ve duygusal taleplerin fazla olduğu ortamlarda uzun süre çalışan, idealist bireylerde görülmekte olduğu belirtilmektedir (Rice 1992; Bakker ve diğ., 2000). Duygusal, zihinsel ve fiziksel yorgunluk durumlarını ifade eden tükenmişlik zaman içerisinde, sinsice gelişen bir süreç olmaktadır. (Maslach ve diğ., 1984; Cordes ve Dougherty, 1993; Maslach ve diğ., 2001).

Tükenmişlik yaşayan kişi, genelde kişisel, mesleki doyumsuzluk ve yorgunluğun karmaşık duygularını yaşadığının farkına varmakta ancak bu duygularin dile getirilmesinin zor oluşu ve belirgin beklentilerin olmayışı bu durumun sıklıkla göz ardı edilmesine neden olmaktadır. Bunun sonucunda, gittikçe artan bir şekilde işten soğuma, işe gitmeyi istememe, yüklenmişlik, tahammülsüzlük, kendinden şüphelenme ve kendilik imajina uygun olmayan şekilde davranma ortaya çikabilmektedir (Maslach ve dĭ̆., 1981; Maslach ve dĭ̆., 1997; Mitchell ve Hastings, 2001; Pines 1993; Rose 1995; ;1999; Schaufeli ve diğ., 1993; Wright ve Cropanzano, 2000).

Tükenmişliğe bireysel ve örgütsel faktörler neden olabilmektedir. Yaş, medeni durum, çocuk sayısı, cinsiyet, kişisel beklen- 
tiler ve arzular, kişilik özellikleri, performans gibi etkenler kişisel nedenler olarak sayılabilir. Yapılan işin niteliği, çalışılan meslek, çalışma alanının fiziksel özellikleri, çalışma süresi, eğitim durumu, alınan kararlarda etki derecesi, diğer çalışanların ve amirlerin desteği ile örgütün yönetim yapısı gibi faktörler ise örgütsel nedenler olarak ele alınabilir (Izgar, 2001).

Tükenmişliğe ait yaygın boyutlandırma Maslach ve Jackson (1981) tarafindan yapılmıştır. Bu çerçevede anılan boyutlar ya da aşamalar, duygusal tükenme, duyarsızlaşma ve kişisel başarı hissinde azalma olarak ifade edilmektedir. Bu boyutlar aşağıda kısaca açıklanmıştır:

Duygusal tükenme: $\mathrm{Bu}$ boyut, bireyin duygusal kaynaklarının tükenmesi ve enerjisinin azalmasını tanımlamaktadır. Duygusal tükenmişlik yaşayan çalışanlar kendilerini işlerine verememektedirler. Duygusal tükenmeyi yaşayan kişi, üzerindeki duygusal yükü hafifletmek için kaçış yolunu kullanmakta ve insanlarla olan ilişkilerini, işin yapılabilmesi için gerekli olan en az düzeye indirmektedir. Ayrıca, insanları kafasında kategorize etme, karşılaştığı kişilere klişeleşmiş kalıplara göre davranma da duygusal tükenme belirtileri olabilmektedir (Basım ve Şeşen, 2005).

Duyarsızlaşma: Tükenmişliğin diğer boyut ya da aşamasını oluşturan bu boyutu ise çalışanın etrafındakilere ya da hizmet sunduğu kişilere karşı takındığ1 olumsuz, ciddiyetten uzak tavır ve duyguları tanımlamaktadır. Bu sendroma giren birey, hizmet sunduğu kişi ya da kişilerin hayatında gereğinden fazla yer tuttuğunu düşünebilmekte; onların hayatından çıkmalarını ve kendisini yalnız bırakmalarını içtenlikle arzu edebilmektedir. Başkaları hakkında geliştirdiği olumsuz düşünce tarzı, kişinin kendisi hakkında da olumsuz düşünmesine yol açabilmekte ve kişi, bu düşünce ve yanlış davranışları nedeniyle kendini çoğunlukla suçlu hissederek kendisi hakkında "başar1sız" hükmünü verebilmektedir. İşte bu noktada, tükenmişliğin üçüncü aşaması olan kişisel başarı hissi azalması ortaya çıkmaktadır (Basım ve Şeşen, 2005).

Kişisel başarı hissinde azalma: Bu boyutun ortaya koyduğu sonuçlar çerçevesinde, bireyler işlerinde başarısız oldukları düşüncesiyle tatminsizlik duymakta ve iş dişındaki faaliyetlere yönelmektedirler (Wright ve Bonett, 1997). İşinde ilerleme kaydetmediğini, hatta gerilediğini düşünen bu tür kişiler, kendilerini suçlu hissetmekte ve harcadıkları çabanın bir işe yaramayacağına inanarak, kendilerine olan saygılarını kaybedip, depresyona girebilmektedirler (Basım ve Şeşen, 2005).

Yukarıda açıklanan boyutlar bağlamında tükenmişlik belirtileri sergileyen bireylerde işi savsaklama, işi bırakma eğiliminde artış, hizmetin niteliğinde bozulma, işe izinsiz gelmeme, izin sonunda rapor ve benzeri yollarla izni uzatma eğilimi, işte ve iş dışında insan ilişkilerinde bozulma ve uyumsuzluk eğilimi, eş ve aile bireylerinden uzaklaşma eğilimi, düşük iş performansı, iş doyumsuzluğu, sebepsiz hastalanma eğilimleri, işteki yaralanma ve iş kazalarında artma gibi olumsuzluklar görülmektedir (Izgar, 2001). Ayrıca, tükenmişliğe maruz kalan bireylerde birtakım fiziksel ve duygusal sorunlar da ortaya çıkabilmektedir (Basım ve Şeşen, 2005; Geurts ve Gründermann, 1999; Maslach, 1982;Maslach ve diğ., 2001; Rose 1995; Wright ve Cropanzano, 2000).

\section{4. Örgütsel Adalet Algısı, Tükenmişlik ve Örgütsel Vatandaşlık Davranışı İlişkisi}

Adalet algısı bireylerin örgüt içindeki davranışlarını şekillendiren unsurlardan biridir (Nasurdin ve Khuan, 2007). Bu çerçevede, örgütlerde adaletin algılanması, örgütsel faktörlere bağlı olarak, yüksek ya da düşük olabilmektedir (Ambrose, 2002).

Adalet algısındaki bu artıs ya da azalmanın, iş tatmini, performans, örgütsel vatandaşlık davranışları ve iş gücü devri ile ilişkili olduğu ifade edilmektedir (Colquitt ve diğ., 2001). Özellikle, örgütsel vatandaşlık davranışını güdüleyen faktörlerin incelendiği çalışmalarda (Moorman, 1991; Organ, 1998; 
1990), en çok vurgulanan bilişsel faktörün, çalışanların adalete ilişkin algılamaları olduğu görülmektedir. Yöneticileri tarafından adil muamele gördüklerine inanan çalışanların daha fazla örgütsel vatandaşlik davranışları sergilediklerinden (Moorman, 1991) yola çıkılarak, bireylerin örgütsel vatandaşlık gösterdiği yerlerde örgütsel adaletin olduğu ifade edilmektedir (Ortiz, 2000). Bununla birlikte, çalışanlara gösterilen muamelenin örgütsel açıdan gerekli davranışların sergilenmesinde önemli olabildiği belirtilmekte (Konovsky ve Pugh, 1994) ve böylelikle etkileşim adaletinin önemine de vurgu yapilmaktadir.

Adalet algılamalarının olumlu etkisinin aksine, bireyler adaletsizlik algıladıkları zaman üretim hızını ve kalitesini düşürmek yerine örgütsel vatandaşlık davranışları gibi gönüllülüğe dayalı davranışlarını azaltma ya da saklama eğilimi gösterebilmektedirler (İşbaş1, 2000: 23-24). Bireylerin örgütsel vatandaşlık davranışlarından vazgeçme yönünde davranmasının nedeninin, örgütsel adaletsizliği algılayan bireyin, biçimsel iş taniminda belirtilen görevleri tam olarak yerine getirmediği takdirde biçimsel ödüllerden mahrum kalabileceğini bilmesi ve örgütsel vatandaşlık davranışlarını azaltma yolunu tercih etmesi olarak ifade edilmektedir (İşbaşı, 2000; Moorman, 1991; Organ, 1998).

Bireylerin, adalet algılamaları ve tükenmişlik düzeyleri dikkate alındığında, örgüt içindeki tükenmişliğinin adalet algılaması ile birlikte değişime uğrayabildiği görülmektedir. Bu bağlamda, bireylerin örgüt içindeki uygulamaları adil olarak algılamaları, onların geliştirdikleri olumsuz tutumları yumuşatmaktadır (Folger ve di ğ., 1999). Bireylerin adalet algılarının yüksek olması, onların motive edilmesini sağlamakta (Lambert, 2003) ve artan motivasyon da bireylerin tükenmişlik düzeyini azaltabilmektedir (Koustelios ve Tsigilis, 2003). Bu durumu tükenmişlik boyutlarına indirgeyerek ifade edersek, artan adalet algisı bireylerin duygusal tükenmelerini azaltabilmekte ve duyarsızlaşmalarını engelleyebilmektedir.
Bunun sonucu olarak kişisel başarı hissi de yüksek olabilmektedir (Maslach ve diğ., 2001). Bunun aksine, adalet algısının araştırmanın diğger faktörü olan ÖVD ile ilişkisi ele alındığında, bireyler örgütte bir adaletsizlik algıladıkları zaman, gönüllülüğe dayalı davranışlarını azaltmakta ya da saklama eğilimi gösterebilmektedirler (İşbaşı, 2000).

Bunun bir sonucu olarak da, yukarıda belirtildiği gibi, bireyler biçimsel ödüllerden mahrum kalmamak için, üretim hızını ve kalitesini düşürmek yerine örgütsel vatandaşlık davranışları kapsamında ele alınabilecek olan gönüllülüğe dayalı davranışlarını azaltma ya da saklama eğilimi gösterebilmektedirler (İşbaşı, 2000: 23-24).

Bireylerin tükenmişlik düzeyleri ve gösterdikleri örgütsel vatandaşlık davranışları dikkate alındığında, tükenmişlik sonucunda bireylerde fiziksel ve duygusal sorunlar çımakta olduğu ve bireylerin örgüt içinde istenmeyen davranışlar geliştirdiği görülmektedir (Basım ve Şeşen, 2005; Geurts ve Gründermann, 1999; Izgar, 2001; Maslach, 1982; Maslach ve diğ., 2001; Rose, 1995; Wright ve Cropanzano, 2000). Bunun bir sonucu olarak tükenmişlik yaşayan bireyler örgütsel vatandaşlık davranışı göstermeme eğiliminde olmaktadır (Schepman ve Zarate, 2008; Lambert, 2010).

Bu noktaya kadar ortaya konan çalışmalar da dikkate alındığında, bireylerin örgüt içinde adalet algılamalarının yüksek olmasının, örgüt içindeki davranışlarını olumlu etkilemekte olduğu sonucuna varılmaktadır. Bu olumlu etki, bireylerin üyesi oldukları örgüte yönelik olumlu duygular beslemesine neden olmakta ve bunun sonucunda bireyler örgüte basit bir üyeliğin ötesinde katkıda bulunmaya yönelik davranışlar sergileyebilmektedir. Bu olumlu davranışlardan birinin de ÖVD olduğu görülmektedir. Bunun aksine bireyler adaletsizlik algiladiklarında, yalnızca olumlu duyguları düşmemekte aynı zamanda olumsuz duygular da geliştirebilmektedirler. Bu olumsuz duygulardan biri de tükenmişlik olarak ortaya çıkabilmektedir. Tükenmişlik hem birey hem de 
örgüt için istenmeyen etkilere neden olmakta ve bu noktada bireyler, örgüte yönelik olumlu davranışlar göstermemenin ötesinde örgüte zarar verici davranışlarda da bulunabilmektedir.

Buraya kadar çizilmeye çalışılan kuramsal çerçeve, adalet algısı ile tükenmişlik, adalet algisı ile örgütsel vatandaşlık davranışları ve tükenmişlik ile örgütsel vatandaşlik davranışları arasındaki ilişkileri ifade etmektedir. Örgüt içinde değişen adalet algılaması ile tükenmişlik de örgütsel vatandaşlık davranışları da değişim gösterebilmektedir. Ayrıca, tükenmişlik ile örgütsel vatandaşlık davranışları da birbirleri ile etkileşim içinde bulunmakta, tükenmişlik ÖVD'yi olumsuz etkilemektedir.

Çalışmamız buraya kadar açıklanmaya çalışılan kuramsal gerekçelerden hareketle, adalet algısı, tükenmişlik ve örgütsel vatandaşlık davranışları arasındaki ilişkiler ve bu ilişkiler içinde anılan faktörlerin doğrudan ve dolaylı etkilerini bir arada görmeyi sağlayabilecektir. Bu çerçevede Şekil-1'de gösterilen araştırma modeli kurgulanmıştır. sakoff ve diğ., 2000) rastlanmakla beraber, bu değişkenleri bir arada ele alan çalışmalara pek rastlanmamaktadır. Bu noktadan hareketle, ÖVD'yi destekleyen (adalet algısı) ve etkisini azaltan (tükenmişlik) iki değişkenin ele alınması ve anılan üç değişken arasındaki ilişkilerin bir arada görülebilmesini sağlaması, çalışmanın önemini artırmaktadir.

Kurgulanan araştırma modeli kuramsal çerçevede ifade edilen gerekçelere dayand1rılarak, örgütsel adalet algısı, tükenmişlik ile örgütsel vatandaşlık davranışının diğergamlık, nezaket, vicdanlılık, sivil erdem ve centilmenlik olarak ifade edilen alt boyutlarını kapsamaktadır. Bu doğrultuda çalışmada, söz konusu değişkenler arasındaki ilişkilerin ortaya konmasının yanı sıra aşağıdaki araştırma sorularına yanıt aranmaktadir:

1. Örgütsel adalet alg1sı ve tükenmişlik duyguları örgütsel vatandaşlık davranışını yordamada ne kadar etkilidir?

2. Örgütsel adalet algısının ÖVD üzerinde doğrudan etkisinin yanında tükenmişlik üzerinden dolaylı etkisi nedir?

Şekil 1: Araştırmanın Modeli

\section{YÖNTEM}

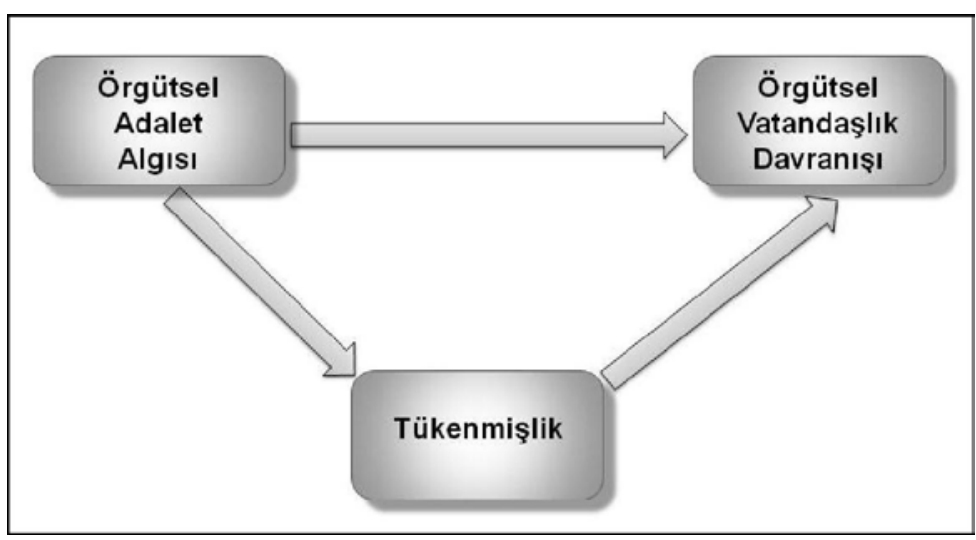

Şekilde görülen araştırma modeli, içerdiği değişkenler ve onların alt değişkenleri arasındaki ilişkileri bütünsel bir yaklaşımla ele almaya yöneliktir. ÖVD'nin öncülleri ile olan ikili ilişkileri inceleyen çalışmalara (LePine ve diğ., 2002; Organ ve Ryan, 1995; Pod-

\section{1. Örneklem}

Araştırmaya, çeşitli bakanlıklar ve bunların bağlı/ilgili kuruluşlarında; şef, kısım amiri ve şube müdürü pozisyonlarında görev yapan 116 alt ve orta kademe yöneticisi katılmıştır. Katılımcıların yaşları 25 ile 42 yıl arasinda $\quad(\mathrm{Ort}=35,08$; ss $=4,14)$; kurumda çalışma süreleri ise 5 ile 23 y1l arasında değişmektedir (Ort= $12,05 ; \mathrm{ss}=4,61)$. Kattlımciların \%81,9'u ( $\mathrm{n}=95)$ lisans ve \%18,1'i ( $n=21)$ de yüksek lisans derecesine sahiptir. Veriler, ölçüm araçlarının yüz yüze iletişimle ve nezaret altında katılımcılara uygulanması ile elde edilmiştir. 


\section{2. Ölçüm Araçları}

\section{Örgütsel Adalet Algısı Ölçeği}

Örgütsel adalet algısı ölçeği (ÖAAÖ), İşbaşı $(2000 ; 2001)$ tarafından geliştirilmiştir. Ölçekte, "Kurumun işleyişine yönelik kurallar, yöneticinin karar alabilmesi için gerekli olan doğru bilgileri sağlar", "Kurumun kaynaklarından ihtiyaçlarımız ölçüsünde eşit biçimde yararlanabiliriz" ya da "Amirimiz, düşüncelerimizi dikkate alır" gibi ifadelerden oluşan 27 madde yer almakta ve kat1lımcılara beşli Likert tipinde belirtilen bu ifadeleri hangi katılım düzeyinde (1- Hiç Katılmiyorum; 5- Tamamen Katıliyorum) onayladıkları sorulmaktadır. Ölçek, dağıtım adaleti (7 madde), süreç adaleti (7 madde), etkileşim adaleti (13 madde) alt boyutlarından oluşmaktadır.

İşbaşı (2000, 2001), çalışmasında ölçeğin toplam güvenirliğini (Cronbach alfa), 93 olarak belirtmiştir. Ölçek daha sonra bir başka çalışmada (Dilek, 2004) kullanılmış ve bu çalışmada, gerek faktör yüklenimleri gerekse ölçeğin güvenilirliği $(\alpha=, 93)$ açısından İşbaşı (2000; 2001)'nın elde ettiği bulgulara yakın sonuçlar elde edilmiştir. Bu çalışmada ise ölçeğin toplam güvenilirliği , 95 olarak hesaplanmiştır.

\section{Tükenmișlik Ölçeği}

Araştırmada katılımcıların tükenmişlik düzeylerini ölçmek üzere Türkçeye Ergin (1992) tarafından çevrilmiş olan Maslach Tükenmişlik Envanteri (MTE) (Maslach ve Jackson, 1981) kullanılmıştır. Ölçekte "İş günüm sonunda kendimi bitkin hissediyorum", "İşimin beni tükettiğini hissediyorum", "İşimin beni hayal kırıklığına uğrattığını düşünüyorum" ya da "İnsanların bazı problemleri için beni suçladıklarını hissediyorum" gibi ifadelerden oluşan 22 madde yer almaktadır. Katılımcılardan ölçekte bulunan çeşitli yargı cümlelerine hangi oranda katıldıklarını 7'li Likert tipi ölçek üzerinde, 0 (hiçbir zaman) ile 6 (her gün) arasında değişen bir aralıkta işaretlemeleri istenmiştir. Ölçek, duygusal tükenme (9 madde), duyarsızlaşma (5 madde) ve düşük kişisel başarı hissi (8 madde) olmak üzere üç alt boyuttan oluşmaktadır. Duygusal tükenme ve duyarsızlaşma alt ölçeğinden alınan yüksek puan ve kişisel başarı alt ölçeğinden alınan düşük puan tükenmişliği göstermektedir. Analiz sırasında kolaylık sağlamak ve karışıklığın önüne geçebilmek için düşük kişisel başarı puanları ters çevrilmiştir.

Ölçeğin Türkiye'deki geçerlik ve güvenirlik çalışmaları Ergin (1992) tarafından yapılmıştır. Ergin (1992) üç boyuta ait Cronbach alfa güvenirlik katsayılarını duygusal tükenme için ,83; duyarsızlaşma için ,65 ve kişisel başarı hissi için ,72 olarak bulmuştur. Daha sonra yapilan bir diğer çalışmada, ölçeğin bütünü için Cronbach alfa katsayıs1 ,76; alt ölçeklerin güvenirlik katsayıları ise sırasılyla ,85; ,72 ve, 73 olarak bulunmuştur (Basım ve Şeşen, 2005). Bu çalışmada ise anılan katsayılar, duygusal tükenme için ,83; duyarsızlaşma için ,71 ve kişisel başarı hissi azalması için ,80; ölçeğin bütünü için ise ,72 olarak hesaplanmıştır.

\section{Örgütsel Vatandaşlık Davranışı Ölçeği}

Örgütsel Vatandaşlık Davranışı Ölçeği (ÖVDÖ). Çalışanların örgütsel vatandaşlık davranışlarını ölçmek için, iki ayrı çalışmadan (Vey ve Campbell, 2004; Williams ve Shiaw, 1999) yararlanılarak, Basım ve Şeşen (2006) tarafından geliştirilen ölçek kullanılmıştır. Ölçekte "Aşırı iş yükü ile uğraşan bir kurum çalışanına yardım ederim", "Mesai içerisinde kişisel işlerim için zaman harcamam", "Önemsiz sorunlar için şikâyet ederek vaktimi boşa harcamam", "Kurum yapısında gerçekleştirilen değişikliklere destek olurum" gibi yarg1 cümlelerinden oluşan 19 madde yer almaktadır. Ölçek, örgütsel vatandaşlık davranışını, Organ (1988) tarafından ortaya konulan diğergamlık (5 madde), vicdanlılik (3 madde), nezaket (3 madde), centilmenlik (4 madde) ve sivil erdem (4 madde) boyutları altında ölçmek üzere tasarlanmıştır. Anket katılanlardan bu yarg1 cümlelerine hangi oranda katıldıklarını 6'lı Likert tipi ölçek üzerinde, "hiçbir zaman" ile "her zaman" arasında değişen bir sıklık aralığında işaretlemeleri istenmiştir. 
Basım ve Şeşen (2006)'in ölçek geliştirme çalışması kapsamında iki ayrı örneklemde güvenilirlik analizi yapılmış; birinci örneklem için hesaplanan ÖVD alt boyutları Cronbach alfa değerlerinin ,75 ile ,86 arasında değiştiği, ölçeğin toplam güvenirliğinin ise , 89 olduğu görülmüştür. İkinci örneklemde ise anılan alt boyutlara ilişkin söz konusu değerlerin ,77 ile ,87 arasında değiştiği görülmüş, ölçeğin toplam güvenirliği de ,94 olarak hesaplanmıştır.

Mevcut çalışmada ise ölçeğinin toplam güvenilirliği ,87 olarak bulunmuş; alt boyutlar bazında güvenilirlik değerleri ,65 ile, 75 arasında değişmiştir.

\section{Ölçeklerin Geçerliliği}

Kullanılan ölçeklerin geçerliliğini test etmek için doğrulayıcı faktör analizi (DFA) yapılmıştır. DFA ile ÖAAÖ'nün üç faktörlü yapısı (dağıtım adaleti, süreç adaleti ve etkileşim adaleti), MTE'nin üç faktörlü yapısı (duygusal tükenme, duyarsızlaşma ve düşük kişisel başarı hissi), ve ÖVDÖ'nün beş faktörlü yapısı (diğergamlık, vicdanlılık, nezaket, centilmenlik ve sivil erdem) tekrar test edilmiştir. Tablo-1'de sunulan doğrulayııı faktör analizi bulgularından anlaşılacağ1 üzere anılan faktör yapıları doğrulanmıştır.
Uyum indeks değerlerinin arzu edilir düzeyde olması nedeniyle (Meydan ve Şeşen, 2011: 37), ölçeklerin kabul edilebilir geçerlilikte olduğu değerlendirilmiştir.

\section{BULGULAR}

Uygulama sonucunda değişkenlere ve boyutlara ait ortalamalar hesaplanmış ve Tablo-2'de gösterilmiştir. Bireylerin örgütsel adalet algıları incelendiğinde, çalıştıkları kurum ile ilgili adalet algılarının pek yüksek olmadığ1 (Genel Adalet Alg1sı Ort=2,56, $\mathrm{ss}=, 73$; Dağıtım Adaleti Ort $=2,19$, $\mathrm{ss}=, 82$; Süreç Adaleti Ort $=2,79$, ss=,81; Etkileşim Adaleti Ort=2,62, ss=,93) görülmektedir. Tükenmişlik ile ilgili sonuçlar incelendiğinde, genel tükenmişlik (Ort=2,87, ss=,38), duygusal tükenme (Ort=2,52, ss=,79), duyarsızlaşma (Ort=1,80, ss=,69), düşük kişisel başarı hislerinin (Ort $=4,27$, ss=,73) diğer bir deyişle bireylerin tükenmişlik düzeylerinin görece düşük olduğu tespit edilmiştir. Örgütsel vatandaşlık düzeylerinin ise, ortalamanın biraz üzerinde (Örgütsel Vatandaşlık Davranışı Ort $=4,75$, ss $=, 55$; diğergamlik Ort $=5,478$, $\mathrm{ss}=, 867$; nezaket Ort $=5,38$, ss $=, 57$; vicdanlilık Ort $=4,56$, ss $=, 82$; sivil erdem Ort $=4,63, \mathrm{ss}=, 71$ ve centilmenlik Ort=4,65, ss=,81) olduğu görülmektedir.

\section{Tablo 1}

Ölçeklerin Doğrulayıcı Faktör Analizi Sonuçları ve Güvenilirlik Değerleri

\begin{tabular}{|l|c|c|c|c|c|c|c|}
\hline Ölçek & $\Delta \boldsymbol{\chi}^{\mathbf{2}}$ & $\mathbf{s d}$ & $\Delta \boldsymbol{\chi}^{2} / \mathbf{s d}$ & RMSEA & CFI & IFI & $\boldsymbol{\alpha}$ \\
\hline ÖAAÖ & $502,8^{*}$ & 321 & 1,57 &, 07 &, 92 &, 92 &, 95 \\
\hline MTE & $416,3^{*}$ & 87 & 1,68 &, 08 &, 90 &, 91 &, 72 \\
\hline ÖVDÖ & $211,20^{*}$ & 146 & 1,44 &, 06 &, 94 &, 94 &, 87 \\
\hline
\end{tabular}

ÖAAÖ: Örgütsel Adalet Algısı Ölçeği, MTE: Maslach Tükenmişlik Envanteri, ÖVDÖ: Örgütsel Vatandaşlık Davranışı Ölçe ği, RMSEA = Root Mean Square Error of Approximation; CFI = Comparative Fit Index; IFI = Incremental Fit Index

\section{Tablo 2}

Ortalamalar, Standart Sapmalar, En Düşük ve En Yüksek Değerler

\begin{tabular}{|l|c|c|c|c|}
\hline Değişken & Ort. & S.S. & En Düşük & En Yüksek \\
\hline 1. Adalet Algısı & 2,56 &, 731 & 1,32 & 4,57 \\
\hline 2. Tükenmişlik & 2,87 &, 383 & 2,00 & 4,16 \\
\hline 3. Örgütsel Vatandaşlık Davranış1 & 4,75 &, 551 & 2,90 & 5,94 \\
\hline
\end{tabular}


Adalet algısı, tükenmişlik ve ÖVD arasındaki ilişkiler Şekil-2'de gösterilmiştir. Adalet algısının tükenmişlik üzerindeki etkisi incelendiğinde, orta düzeyde anlamlı ilişki $(\beta=-, 40, p<, 01)$, adalet algısı ve örgütsel vatandaşlık davranışı boyutları arasındaki etki incelendiğinde, diğergamlık $(\beta=, 04$, $\mathrm{p}<, 05)$, nezaket $(\beta=, 15, \mathrm{p}<, 05)$ boyutları ile düşük düzeyde anlamlı ilişki ve tükenmişlik ve örgütsel vatandaşlık davranışı arasındaki etkileşim incelendiğinde ise Diğergamlık $(\beta=, 69, p<, 01)$, nezaket $(\beta=, 75$, $\mathrm{p}<, 01)$, vicdanlilık $(\beta=, 65, \mathrm{p}<, 01)$, sivil erdem $(\beta=, 83, \mathrm{p}<, 01)$, ve centilmenlik $(\beta=, 78, \mathrm{p}<, 01)$ boyutlarında orta düzeyin üzerinde anlamlı etki olduğu görülmektedir.

Adalet algısının tükenmişlik ve örgütsel vatandaşlık davranışı, ve tükenmişliğin ör- gütsel vatandaşlık davranışı üzerindeki etkisini ölçmek üzere kurulan araştırma modelinin uyum değerleri de Tablo-3'te verilmiştir. $\mathrm{Bu}$ sonuçlar modelin yeterli uyum sağladığını göstermektedir.

Yapısal eşitlik modelinde yukarıda belirtilen doğrudan etkilerin haricinde dolaylı etkileri de ortaya koymak mümkündür. Bir değişkenin diğer değişken üzerindeki dolaylı etkisi bir aracı değişken üzerinden olmakta ve sonuçta bağımlı değiş̧kenin bağımsız değişken tarafından yordanma şekli hakkında daha ayrıntılı bilgiye sahip olunabilmektedir. Bu çalışmada ortaya konmaya çalışılan değişkenlere ait doğrudan, dolaylı ve toplam etkiler Tablo-4'te verilmiştir.

\section{Tablo3}

Model uyum değerleri

\begin{tabular}{|c|c|c|c|c|c|c|c|}
\hline$\Delta \chi^{2}$ & sd & $\Delta \chi^{2} / \mathrm{sd}$ & RMSEA & GFI & AGFI & CFI & IFI \\
\hline $54,539^{*}$ & 16 & 3,409 &, 088 &, 92 &, 82 &, 921 &, 923 \\
\hline
\end{tabular}

${ }^{*} p>, 05$

Şekil 2: Yapısal eşitlik modeline ait doğrudan etkiler

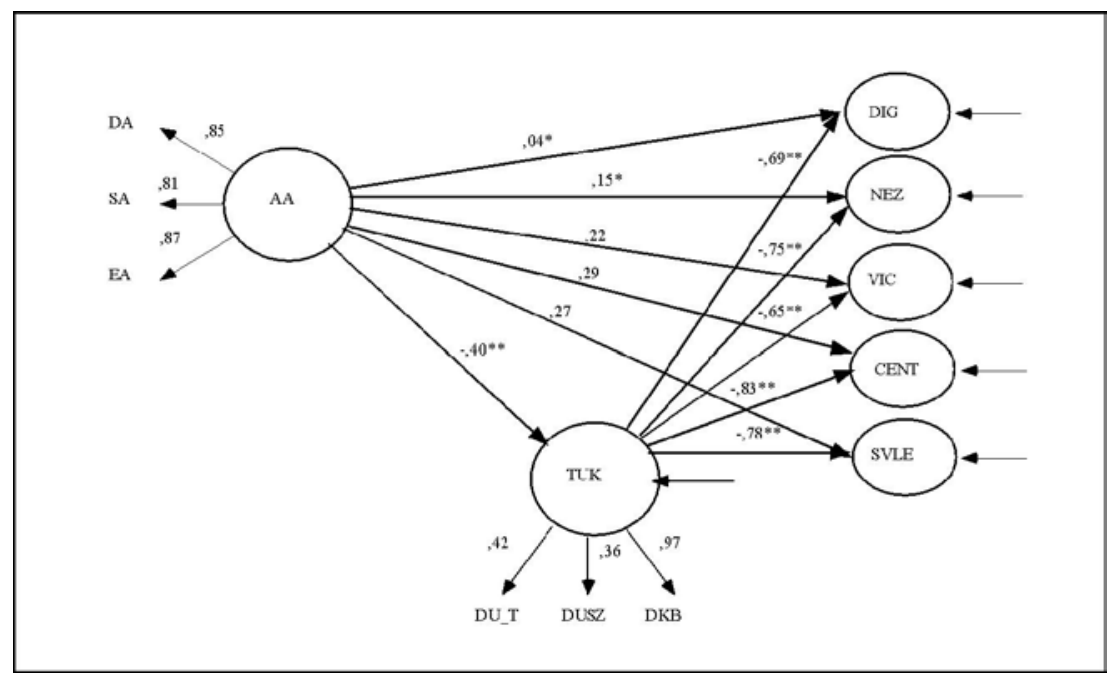

${ }^{*} p<.05,{ }^{* *} p<.01,{ }^{* * *} p<.001$

AA: Adalet Algısı, DA: Dağıtım Adaleti,SA: Süreç Adaleti, EA: Etkileşim Adaleti, TUK: Tükenmişlik, DU T: Duygusal Tükenme, DUSZ: Duyarsızlaşma, DKB: Düşük Kişisel Başarı, DIG: Diğergamlık, NEZ: Nezaket, VIC: Vicdanlılık, CENT: Centilmenlik, SVLE: Sivil Erdem 
Tablo 4

Toplam Doğrudan ve Dolaylı Etkiler

\begin{tabular}{|c|c|c|c|c|c|c|}
\hline & \multicolumn{3}{|c|}{ Adalet Alg1sı } & \multicolumn{3}{|c|}{ Tükenmişlik } \\
\hline & \multicolumn{3}{|c|}{ Etkiler } & \multicolumn{3}{|c|}{ Etkiler } \\
\hline & Toplam & Doğrudan & $\overline{\text { Dolayll }}$ & Toplam & Doğrudan & Dolaylı \\
\hline Tükenmişlik &,$- 40^{* *}$ &,$- 40^{* *}$ & - & - & - & - \\
\hline Diğergamlık & $21^{*}$ &, $04^{*}$ & $17^{* *}$ &,$- 78^{* *}$ &,$- 78^{* *}$ & - \\
\hline Nezaket & $19^{*}$ & $15^{*}$ &, $04^{*}$ &,$- 83^{* *}$ &,$- 83^{* *}$ & - \\
\hline Vicdanlılık & $34^{*}$ & 22 & $12^{* *}$ &,$- 65^{* *}$ &,$- 65^{* *}$ & - \\
\hline Centilmenlik & $46^{*}$ & 29 & $17^{* *}$ &,$- 75^{* *}$ &,$- 75^{* *}$ & - \\
\hline Sivil Erdem & $47^{* *}$ & ,27 & $19^{* *}$ &,$- 69^{* *}$ &,$- 69^{* *}$ & - \\
\hline
\end{tabular}

${ }^{*} p<, 05,{ }^{* *} p<, 01$

Doğrudan, dolaylı ve toplam etkiler incelendiğinde, adalet algısının, tükenmişlik üzerinde olumsuz yönlü ve örgütsel vatandaşlık davranışları boyutlarından diğergamlık ve nezaket üzerinde olumlu yönde, zayıf, doğrudan etkisinin olduğu; bunun yanı sıra, örgütsel vatandaşlık davranışının tüm boyutları üzerinde olumlu yönde dolaylı etkisinin olduğu görülmektedir. Tükenmişliğin ÖVD boyutları üzerindeki etkileri incelendiğinde, tüm boyutlar üzerinde yüksek düzeyde, ters yönlü ve doğrudan ilişkinin olduğu görülmektedir. Adalet algısının etkilerinin dolaylı olması, bu etkilerin tükenmişlik aracılığıyla olduğunu da göstermektedir.

\section{TARTIŞMA VE SONUÇ}

Bu çalışmanın amacı örgütsel adalet algisı ve tükenmişlik ile ÖVD arasındaki ilişkiyi inceleyerek, aralarındaki etkileşimi ve adalet alg1sı ve tükenmişliğin ÖVD üzerindeki öncüllük rolünü ortaya koymaktır. Daha önce adalet algısı ile ÖVD arasındaki doğrusal ilişkinin ortaya konmasına yönelik yapılmiş olan çalışmalar bulunmakta, ancak, ikiden çok değişkeni bir arada ele alan çalışmalara pek rastlanmamaktadır. Bu çalışma, geçmişteki çalışmalardan farklı olarak, anılan üç değişkeni birlikte ele alarak incelemekte ve bütüncül bir bakış açısıyla odaklanılan ilişkileri ortaya koymak suretiyle hem ilgili yazına katkı sağlamayı hem de yönetsel/örgütsel uygulamalarda yöne- ticilere kolaylıklar sunacak bulgular elde etmeyi hedeflemektedir.

Elde edilen bulgular örgütsel adalet alg1sı ile ÖVD arasındaki etkileşime odaklanan daha önce yapılmış çalışmaları desteklemektedir (Chegini, 2009; Ehrhart, 2004; İşbaş1, 2001; Rifai, 2005; Teper ve Taylor, 2003; Zellars ve diğ., 2003). Ayrıca, tükenmişliğin de ÖVD üzerindeki etkisi ve adalet alg1s1ÖVD arasındaki ilişkide tükenmişliğin aracı rolü olabileceği ortaya konmaktadır.

Çalışmanın bulguları incelendiğinde araştırma sorularına yönelik olarak aşağ ${ }^{-}$ daki yanıtların bulunduğu görülmektedir. Bireyin adalet algisına sahip olmasının tükenmişlik duyguları üzerinde azaltıcı yönde bir etkiye sahip olduğu ve bireylerin tükenmişlik duygularının ÖVD'nin önemli bir yordayıcısı olduğu görülmektedir. Bu bulgular daha önce yapılmış çalışmaları desteklemektedir (Van Emmerik ve diğ., 2005; Yücel ve diğ., 2009). Ayrica adalet algısının örgütsel vatandaşlık davranışları üzerinde hem doğrudan hem de tükenmişlik üzerinden dolaylı olarak etkisi bulunduğu ortaya konmuştur.

Bu bulguların yanı sira, adalet algısının ÖVD'nin diğergamlık ve nezaket boyutları üzerinde doğrudan etkili olduğu görülmektedir. Bu durum ÖVD'nin kişiye yönelik olarak da ifade edilen boyutları üzerinde adalet algısının kendisini direk olarak gösterdiğini ortaya çıkarmaktadır. Daha önceki çalışma- 


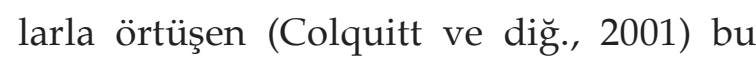
bulgu adalet algılarının örgüt içinde diğer bireylerle olan ilişkilerin kalitesine önemli etkisinin olması (Masterson ve diğ., 2000) ve bireylerin adalet algılamalarını örgütsel süreçler ile ilişkilendirmekte olmaları, çalışma arkadaşlarının da örgütün bir parçası olarak görmelerinden kaynaklanabileceği ile açılanabilir. Bununla birlikte, adalet alg1sı ÖVD'nin diğer boyutları üzerinde dolaylı etkiye sahiptir.

Örgütsel adalet alg1sı, hem süreçleri içine alan örgüt yapısı ile ilgili adalet algılamalarını, hem de bireylerin liderleri ile aralarındaki etkileşimi içeren adalet algılamalarını kapsamaktadır. Örgüt içinde adalet algılamasının yüksek olması bireylerin tükenme duyguları üzerinde ters yönde bir etkiye sahip olmakta, bunun sonucunda ortaya çıkan düşük tükenmişlik hissi bireylerin ÖVD sergilemelerine neden olmaktadır. Adalet algısının ÖVD üzerindeki toplam etkisi dikkate alındığında örgüte yönelik ÖVD üzerinde daha fazla etkinin olduğu görülmektedir. Bu durum, adaletin örgütsel süreçlerle ilişkisinin yüksek olduğu değerlendirildiğinde, beklenen bir sonuçtur.

Ulaşılan bulgular bireylerin ÖVD göstermesinde adalet algısının ve tükenmişliğin önemli birer örgütsel değişken olduğunu, aynı zamanda örgüt içinde adalet algılamalarının örgütsel diğer değişkenler üzerinde etkili olduğunu göstermektedir. Zira adalet algısı hem tükenmişlik hissi üzerinde hem de ÖVD üzerinde etkili olabilmektedir.

Ulaşılan bulgular yönetsel/örgütsel ortam ve uygulamalar için kullanılabilecek ve bu çerçevede yarar sağlayabilecek bazı sonuçları ortaya koymaktadır. Bireylerin, örgütsel başarı, verimlilik ve etkililiğin artmasında önemli bir faktör olan ÖVD'larını daha fazla gösterebilmesi için, örgütsel süreçlerin iyileştirilmesi gerektiği değerlendirilmektedir. Çünkü bireyler, kararlara ulaşmada kullanılan süreçlerin adilliğini önemsemektedir. Yöneticilerin örgüt içinde adaleti sağlamaya yönelik davranışları bireylerin aynı zamanda tükenmişlik düzeylerini azaltıcı et- kiye sahip olabilecektir. Bu durum bireylerin hem iş arkadaşlarına hem de iş yerlerine karşı gösterdikleri ÖVD'larını olumlu olarak etkileyebilecektir. Daha önceki araştırmalarda ortaya konduğu üzere (Lapierre ve Hackett, 2007) bu durum örgütsel performansı artırabilecektir.

$\mathrm{Bu}$ bulguların yanında çalışmamız bazı sinırlılıklar da içermektedir. Araştırmada kullanılan örneklem kamu sektöründe belirli pozisyonlarda görev yapan, belirli sayıda yöneticiden oluşmaktadır. Dolayısıyla, nicelik ve nitelik olarak farklılaştırılmış örneklem gruplarıyla yürütülecek çalışmalar daha sağlıklı ve genellenebilir sonuçlara ulaşma imkânı sağlayacaktır. Bunların yanı sıra, veriler kişilerin yalnızca kendi değerlendirmelerini yansıttığından, ortak yöntem varyansı ve sosyal beğenirlik etkisi sınırlılıkları ile araştırmanın kesitsel veri kullanılarak gerçekleştirilmiş olması, sonuçların değerlendirilmesinde dikkate alınmalıdır. 


\section{References}

Adams, J. S. (1965), Inequity in Social Exchange, Berkowitz L. (Ed.), Advances in Experimental Social Psychology, 2: 267-299.

Ambrose, M. (2002), Contemporary Justice Research: A New Look At Familiar Questions, Organizational Behavior and Human Decision Processes, 89: 803-812. doi:10.1016/S0749-5978(02)00030-4

Andersson-Stråberg, T., Sverke M. ve Hellgren J. (2007), Perceptions of Justice in Connection with Individualized Pay, Economic and Industrial Democracy, 28: 431-464. doi:10.1177/0143831X07079356

Bakker, A. B., Schaufeli, W. B., Demerouti, E., Janssen, P. M. P., Van Der Hulst, R. ve Brouwer, J. (2002), Using Equity Theory to Examine the Difference Between Burnout and Depression, Anxiety, Stress and Coping, 13: 247-268.

Barksdale, K. ve Werner, J. M. (2001), Managerial Ratings of In-Role Behaviors, Organizational Citizenship Behaviors and Overall Performance: Testing Different Models of Their Relationship, Journal of Business Research, 51: 145155.

doi:10.1016/S0148-2963(99)00061-2

Basım, H. N. ve Şeşen, H. (2005), Çalışma Yaşamında Tükenmişlik: Sosyal Hizmet Uzmanları ile Hemşireler Üzerine Karşılaştırmalı Bir Çalışma, Toplum ve Sosyal Hizmet, 16, 2: 57-70.

Basım, H. N. ve Şeşen, H. (2006), Örgütsel Vatandaşlık Davranışı Ölçeği Uyarlama ve Karşılaştırma Çalışması, Ankara Üniversitesi SBF Dergisi, 61, 4: 83-102.
Bateman, T. S. ve Organ, D. W. (1983), Job Satisfaction and the Good Soldier: The Relationship between Affect and Employee Citizenship. Academy of Management Journal, 26: 587-595. doi:10.2307/255908

Bies, R. ve Moag, J. (1986), Interactional Justice: Communication Criteria of Fairness, Research on Negotiation in Organizations, 1, Greenwich, CT: JAI Press.

Bolino, M. C. (1999), Citizenship and Impression Management: Good Soldiers or Good Actors?, Academy of Management Review, January: 82-98. doi:10.2307/259038

Bommer, W. ve Lily, B. (1999), Supervisors as Stewards of Organizational Citizenship, An Examination of the Agreement Between within and Across group Effects of Employee OCB's on the Overall Performance, National Meeting of The Academy of Management, Chicago, IL.

Brief, A. P. ve Motowidlo, S. J. (1986), Prosocial Organizational Behaviors, Academy of Management Review, 11, 4: 710-725. doi: $10.2307 / 258391$

Burns, B. M. ve Collins, R. W. (2000), Organizational Citizenship Behavior in the US Context, http//hsb.baylor.edu/ ramsower/acis/papers/burns.htm, (Erişim T: 21.01.2010).

Chegini, M.G. (2009), The Relationship between Organizational Justice and Organizational Citizenship Behavior, American Journal of Economics and Business Administration, 1, 2: 171-174.

Cohen-Charash, Y. ve Spector, P.E. (2001), The Role of Justice in Organizations: A Meta-analysis, Organizational Behavior and Human Decision Processes, 86: 278-321. 
Colquitt, J. A. (2001), On the Dimensionality of Organizational Justice: A Construct Validation of A Measure, Journal of Applied Psychology, 86: 386-400. doi:10.1037/0021-9010.86.3.386 PMid:11419799

Colquitt, J.A., Conlon, D.E., Wesson, M.J., Porter, C.O.L.H. ve Ng, K.Y. (2001), Justice at the Millennium: A MetaAnalytic Review of 25 Years of Organizational Justice Research. Journal of Applied Psychology, 86: 425-445.

Cordes, C. L. ve Dougherty, T. W. (1993), A Review and an Integration of Research on Job Burnout, Academy of Management Review, 18: 621-656.

doi:10.2307/258593

Deluga, R. J. (1995), The Relation between Trust in the Supervisor and Subordinate Organizational Citizenship Behavior, Military Psychology, 7, 1: 1-16. doi:10.1207/s15327876mp0701_1

Ehrhart, M. G. (2004), Leadership and Procedural Justice Climate as Antecedents of Unit-Level Organizational Citizenship Behavior, Personnel Psychology, 57: 61-94.

doi:10.1111/j.1744-6570.2004.tb02484.x

Ergin, C. (1992), Doktor ve Hemşirelerde Tükenmişlik ve Maslach Tükenmişlik Ölçeğinin Uyarlanması. (VII. Ulusal Psikoloji Kongresi Bilimsel Çalışmaları), Bayraktar, R. ve Dağ, İ. (Ed.) Ankara: Türk Psikologlar Derneği Yayını: 143-154.

Folger, R. (1998), Fairness as A Moral Virtue, M. Schminke (Ed.), Managerial Ethics: Moral Management of People and Processes, Mahwah, NJ, Erlbaum: 13-34.
Folger, R. ve Skarlicki, D.P. (1999), Unfairness and Resistance to Change: Hardship as Mistreatment, Journal of Organizational Change Management, 12: $35-50$. doi:10.1108/09534819910255306

Freudenberger, H. J. (1974), Staff Burnout, Journal of Social Issues, 30: 159-165. doi:10.1111/j.1540-4560.1974.tb00706.x

Geurts, S. ve Gründermann, R. (1999), Workplace Stress and Stress Prevention in Europe, M. Compier, C. Cooper (Ed.) Preventing Stress, Improving Productivity; European Case Studies in the Workplace, Routledge, London: 9-32.

Graham, J. W. (1989), Organizational Citizenship Behavior: Construct Redefinition, Operationalization and Validation, Yayımlanmamış çalışma, Loyola University of Chicago.

Greenberg, J. (1990), Organizational Justice: Yesterday, Today, and Tomorrow, Journal of Management, 16: 399-432. doi:10.1177/014920639001600208

Greenberg, J. (1993), The social side of fairness: interpersonal and informational classes of organizational justice. R. Cropanzano (Ed.), Justice in the work place: approaching fairness in human resource management, Hillsdale: Erlbaum: 79-103.

Hannam, R. ve Jimmieson N. (2002), The Relationship Between Extra-role Behaviours and Job Burnout for Primary School Teachers: A Preliminary Model and Development of an Organizational Citizenship Behaviour Scale, School of Psychology, University of Queensland, www.aare.edu.au/ 02pap/han02173.htm, (Erişim tarihi: 09.09.2010). 
Hardeep C., (2010), Antecedents And Consequences Of Organisational Citizenship Behaviour (OCB): A Conceptual Framework In Reference To Health Care Sector. Journal of Services Research, 10, 2.

Hoffman, B. J., Blair, C. A., Meriac, J. P. ve Woehr, D. J. (2007), Expanding the Criterion Domain? A Quantitative Review of the OCB Literature. Journal of Applied Psychology, 92, 555-566. doi:10.1037/0021-9010.92.2.555 PMid:17371100

Irak, D.U. (2004), Örgütsel Adalet: Ortaya Çıkışı, Kuramsal Yaklaşımlar ve Bugünkü Durumu, Türk Psikoloji Yazılar1, 7, 13: 25-43.

İşbaşı, J.Ö. (2000), Çalışanların Yöneticilerine Duydukları Güvenin ve Örgütsel Adalete İlişkin Algılamalarının Vatandaşlık Davranışının Oluşumundaki Rolü: Bir Turizm Örgütünde Uygulama, Yayımlanmamış Yüksek Lisans Tezi, Akdeniz Üniversitesi, SBE.

İşbaşı, J.Ö. (2001), Çalışanların Yöneticilerine Duydukları Güvenin ve Örgütsel Adalete İlişkin Algılamalarının Vatandaşlık Davranışının Oluşumundaki Rolü, Yönetim Araştırmaları Dergisi, 1, 1: 51-73.

Izgar, H. (2001). Okul Yöneticilerinde Tükenmişlik, Ankara, Nobel Yayın Dağıtim.

Kidder, D. L. (2002), The Influence of Gender on the Performance of Organizational Citizenship Behaviors, Journal of Management, 28, 5: 629-648. doi:10.1177/014920630202800504

Kidwell, R., Mossholder, K. ve Benneth, N. (1997), Cohesiveness and Organizational Citizenship Behavior, Journal of Management, 23, 6: 775-793. doi:10.1177/014920639702300605
Konovsky, M. A. ve Pugh, S. D. (1994), Citizenship Behavior and Social Exchange, Academy of Management Journal, 37: 656-669. doi:10.2307/256704

Koustelios, A. ve Tsigilis N. (2003), The Relationship between Burnout and Job Satisfaction among Physical Education Teachers: A Multivariate Approach, European Physical Education Review, 1, 2:189-203.

Lambert, E. (2003), The Impact of Organizational Justice on Correctional Staff, Journal of Criminal Justice, 31: 155168. doi:10.1016/S0047-2352(02)00222-2

Lambert, E. (2010), The Relationship of Organizational Citizenship Behavior with Job Satisfaction, Turnover Intent, Life Satisfaction, and Burnout among Correctional Staff, Criminal Justice Studies, 23, 4: 361- 380. doi:10.1080/1478601X.2010.516533

Lapierre L. M. ve Hackett R. D. (2007), Trait Conscientiousness, Leader-Member Exchange, Job Satisfaction and Organizational Citizenship Behaviour: A Test of an Integrative Model, Journal of Occupational and Organizational Psychology, 80: 539-554. doi:10.1348/096317906X154892

Lee, J. (2001), Leader-Member Exchange, Perceived Organizational Justice, and Cooperative Communication, Management Communication Quarterly, 14: 574.

doi:10.1177/0893318901144002

LePine, J. A., Erez, A. ve Johnson, D. E. (2002), The Nature and Dimensionality of Organizational Citizenship Behavior: A Critical Review and MetaAnalysis, Journal of Applied Psychology, 87: 52-65. doi:10.1037/0021-9010.87.1.52 PMid:11916216 
Maslach, C. (1982), Burnout, the Cost of Caring, Prentice Hall, Englewood Cliffs, New Jersey.

Maslach, C. ve Jackson, S. E. (1981), The Measurement of Experienced Burnout, Journal of Occupational Behavior, 2: 99-113. doi:10.1002/job.4030020205

Maslach, C. ve Jackson, S. H. (1984), Patterns of Burnout Among a National Sample of Public Contact Workers, Journal of Health and Human Resource Administration, 7: 189-212.

Maslach, C. ve Leiter M. P. (1997), The Truth about Burnout: How Organizations Cause Personal Stress and What to Do About It, San Francisco, California, Jossey-Bass.

Maslach, C., Schaufeli, W. B. ve Leiter, M. P. (2001) Job Burnout, Annual Review of Psychology, 52: 397-422. doi:10.1146/annurev.psych.52.1.397 PMid:11148311

Masterson, S.S., Lewis, K., Goldman, B.M. ve Taylor, M.S. (2000), Integrating Justice and Social Exchange: The Differing Effects of Fair Procedures and Treatment on Work Relationships", Academy of Management Journal, 43, 4, 738-748. doi:10.2307/1556364

McNeely, B. L. ve Meglino, B. M. (1994), The Role of Dispositional and Situational Antecedents in Prosocial Organizational Behavior: An Examination of the Intended Beneficiaries of Prosocial Behavior, Journal of Applied Psychology, 79, 6: 836-844. doi:10.1037/0021-9010.79.6.836

Meydan, C. H. ve Şeşen, H. (2011). Yapısal Eşitlik Modellemesi AMOS Uygulamaları, Ankara: Detay Yayın.
Mitchell, G. ve Hastings, R. P. (2001). Coping Burnout and Emotion in Staff Working in Community Services for People with Challenging Behaviors, American Journal on Mental Retardation, 106: 448-459. doi:10.1352/08958017(2001)106<0448:CBAEIS>2.0.CO;2

Moorman, R. H. (1991), Relationship Between Organizational Justice and Organizational Citizenship Behaviors: Do Fairness Perceptions Influence Employee Citizenship?, Journal of Applied Psychology, 76: 845-855. doi:10.1037/0021-9010.76.6.845

Nasurdin N. ve Khuan J. (2007), Organizational Justice As An Antecedent Of Job Performance, Gadjah Mada International Journal of Business, September-December, 9, 3: 325-343.

Netemeyer, R., Mc Kee, D. O. ve Mc Murran, R. (1997), An Investigation into The Antecedents of Organizational Citizenship Behavior in a Personnel Selling Context, Journal of Marketing, 61, 3: 85-98.

doi:10.2307/1251791

Nowakovski, J. M. ve Conlon, D. E. (2005), Organizational Justice: Looking Back, Looking Forward, International Journal of Conflict Management, 16, 1: 429.

doi:10.1108/eb022921

O'Reilly, R. ve Chatman, J. (1986), Organizational Commitment and Psychological Attachment: The Effects of Compliance, Identification and Internalization on Prosocial Behavior, Journal of Applied Psychology, 71, 3: 492-499. doi:10.1037/0021-9010.71.3.492

Organ, D. W. (1988), Organizational Citizenship Behavior: The Good Soldier Syndrome, Lexington, England: Lexington Books. 
Organ, D. W. ve Konovsky, M. (1989), Cognitive Versus Affective Determinants of Organizational Citizenship Behavior, Journal of Applied Psychology, 74, 1: 157-164. doi:10.1037/0021-9010.74.1.157

Organ, D. W. ve Moorman, R. H. (1993), Fairness and Organizational Citizenship Behavior: What are the Connections?, Social Justice Research, 6: 5-18. doi:10.1007/BF01048730

Organ, D. W. ve Ryan K. A. (1995), A MetaAnalytic Review of Attitudinal and Dispositional Predictors of Organizational Citizenship Behavior, Personnel Psychology, 48: 775-802. doi:10.1111/j.1744-6570.1995.tb01781.x

Özdevecioğlu, M. (2003), Örgütsel Vatandaşlık Davranışı ile Üniversite Öğrencilerinin Bazı Demografik Özellikleri ve Akademik Başarıları Arasındaki İlişkilerin Belirlenmesine Yönelik Bir Araştırma, Erciyes Üniversitesi İktisadi ve İdari Bilimler Fakültesi Dergisi, 20: 117-135.

Pines, A. M. (1993), Burnout, Handbook of Stress: Theoretical and Clinical Aspects, Goldberger, L. ve Breznitz, S.(Ed.), New York, The Free Press, 386402.

Podsakoff, P. M. ve Mackenzie S. B. (1997), Impact of Organizational Citizenship Behaviour on Organizational Performance: A Review and Suggestions for Future Research; Human Performance, 10 (2), 133-151.

doi:10.1207/s15327043hup1002_5

Podsakoff, P. M., Mackenzie, S. B., Paine, J. B. ve Bachrach. D. G. (2000), Organizational Citizenship Behaviors: A Critical Review of the Theoretical and Empirical Literature and Suggestions for Future Research, Journal of Management, 26, 3: 513-563. doi:10.1177/014920630002600307
Rice, P. L. (1992), Stress and Health, Brooks, Cole Publishing, Pacific Grove, California.

Rose, J. (1995), Stress and Residential Staff: Towards an Integration of Existing Research, Mental Handicap Research, 8: 220-236. doi:10.1111/j.1468-3148.1995.tb00159.x

Rose, J. (1999): Stress and Residential Staff Who Work with People Who Have An Intellectual Disability: A Factor Analytic Study, Journal of Intellectual Disability Research, 43: 268-278. doi:10.1046/j.1365-2788.1999.00210.x PMid:10466864

Ryan, J. J. (2002), Work Values and Organizational Citizenship Behaviors: Values That Work for Employees and Organizations, Journal of Business and Psychology, 17, 1: 123-132. doi:10.1023/A:1016246103190

Schepman S. B. ve Zarate M. A. (2008), The Relationship between Burnout, Negative Affectivity and Organizational Citizenship Behavior for Human Services Employees, International Journal of Human and Social Sciences, 3, 8: 532-537.

Schaufeli, W. B. ve Van Dierendonck, D. (1993), The Construct Validity of Two Burnout Measures, Journal of Organizational Behavior, 14: 631-647. doi:10.1002/job.4030140703

Schnake, M. ve Dumler, M. P. (1993), The Relationship between Traditional Leadership, Super Leadership and Organizational Citizenship Behavior, Group and Organizational Management, 18, 3: 352-366. doi:10.1177/1059601193183006

Smith, C. A., Organ, D. ve Near, Y. (1983), Organizational Citizenship Behavior: Its Nature and Antecedents, Journal of Applied Psychology, 68, 4: 653-663. doi:10.1037/0021-9010.68.4.653 
Thibaut, J., ve Walker, L. (1975). Procedural justice: A psychological analysis, Hillsdale, NJ: Lawrence Erlbaum Associates.

Thompson, H. B. ve Werner, J. M. (1997), The Impact of Role Conflict / Facilitation on Core and Discretionary Behaviors: Testing a Mediated Model, Journal of Management, 23, 4: 583-601. doi:10.1016/S0149-2063(97)90049-0

Turnipseed, D. ve Murkison, G. (1996), Organizational Citizenship Behavior: An Examination of Influence the Workplace, Leadership and Organizational Development Journal, 17: 42-47. doi:10.1108/01437739610111222

Turnipseed, D. ve Murkison, G. (2000), Good Soldiers and Their Syndrome: Organizational Citizenship Behavior and the Work Environment, North American Journal of Psychology, 2, 2: 1-16.

Van Dyne, L., Graham, J. W. ve Dienesch, R. M. (1994), Organization Citizenship Behavior: Construct, Redefinition, Measurement and Validation, Academy of Management Journal, 37, 4, 765-802.

doi: $10.2307 / 256600$

Van Emmerik, I., Hetty, J. I. M. ve Stone, T. H. (2005), Associations Among Altruism, Burnout Dimensions, and Organizational Citizenship Behavior, Work \& Stress, 19, 1: 93-100. doi:10.1080/02678370500046283

Van Scotter, J. R. ve Motowidlo, S. J. (1996), Evidence for Two Factors of Contextual Performance: Job Dedication and Interpersonal Facilitation, Journal of Applied Psychology, 81: 525-531. doi:10.1037/0021-9010.81.5.525
Vey, M. A. ve Campbell. J. P. (2004), InRole or Extra-Role Organizational Citizenship Behavior: Which Are We Measuring?, Human Performance, 17, 1: 119-135 doi:10.1207/S15327043HUP1701_6

Viswesvaran, C. ve Ones, D. S. (2003), Examining the Construct of Organizational Justice, Journal of Business Ethics, 38: 193-203. doi:10.1023/A:1015820708345

Williams, L. J. ve Anderson, S. E. (1991), Job Satisfaction and Organizational Commitment as Predictors of Organizational Citizenship and In-Role Behavior, Journal of Management, 17: 601-17. doi:10.1177/014920639101700305

Williams, S. ve Shiaw, W. T. (1999), Mood and Organizational Citizenship Behavior: The Effects of Positive Affect on Employee OCB Intentions, The Journal of Psychology, 133, 6: 656-668. doi:10.1080/00223989909599771 PMid:10589519

Wright, T. A. ve Bonett, D. G. (1997), The Contribution of Burnout to Work Performance, Journal of Organizational Behavior, 18: 491-499. doi:10.1002/(SICI)10991379(199709)18:5<491::AIDJOB804>3.0.CO;2-I

Wright, T. A. ve Cropanzano, R. (2000), Psychological Well-being and Job Satisfaction as Predictors of Job Performance, Journal of Occupational Health Psychology, 5: 84-94. doi:10.1037/1076-8998.5.1.84 PMid:10658888

Yücel, C., Yalçın, M. ve Ay, B. (2009), Öğretmenlerin Öz-Yeterlikleri ve Örgütsel Vatandaşlık Davranışı, MANAS Sosyal Bilimler Dergisi, 21: 221,235. 
Zellars, K. L., Teper, B. J., Giacalone, R. A., Lockhart, D. ve Jurkiewicz, C. L. (2003), Justice and Organizational Citizenship: Interactive Effects of Impression Management Motives, Academy of Management Proceedings: 1-9.

Zhang, H. (2006), Antecedents and Consequences of Organizational Justice: An Investigation in China, Ph.D. Thesis, McMaster University 